\title{
Unravelling zinc and lead distributions in dolomitic and metapelitic soils of the Brazilian Central Plateau: insight from physical fractionation, optical microscopy and X-ray microfluorescence
}

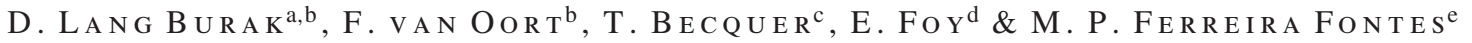 \\ ${ }^{\mathrm{a}}$ Departamento de Produção Vegetal, Universidade Federal do Espírito Santo, 29500-000 Alegre, Brazil, ${ }^{\mathrm{b}}$ INRA, UR251 Pessac, RD 10, \\ F-78026 Versailles Cedex, France, ' $I R D$, UMR210 Eco\&Sols, CIRAD-INRA-SupAgro, 2 Place Viala, F-34060 Montpellier Cedex 1, \\ France, ${ }^{\mathrm{d}}$ CEA-CNRS, UMR3299, SIS2M-LAPA, CEA-Saclay, F-91191 Gif-sur-Yvette Cedex, France, and ${ }^{\mathrm{e} D e p a r t a m e n t o ~ d e ~ S o l o s, ~}$ \\ Universidade Federal de Viçosa, 29570-000 Viçosa, Brazil
}

\begin{abstract}
Summary
Large zinc and lead concentrations occur in strongly weathered soils of Cambisol-Ferralsol toposequences in the Paracatu-Vazante area (Central Plateau, Brazil). Weathering of the mineralized dolomite parent material of the Cambisols is hypothesized to be the geogenic source of zinc $(\mathrm{Zn})$ and lead $(\mathrm{Pb})$, with dissemination downslope into the Ferralsols. This leads to different metal distribution patterns in the two soils. We studied Zn and $\mathrm{Pb}$ distributions in selected $\mathrm{A}$ and $\mathrm{B}$ horizons of two typical profiles to examine this hypothesis and assess the contribution of sesquioxides to the retention of these metals. Physical separation into 200-2000, 50-200, $20-50$ and $<20-\mu \mathrm{m}$ size fractions in water without chemical dispersants was carried out before (F1) and after (F2) ultrasonification. The fractions were analysed for total and extractable $\mathrm{Zn}$ and $\mathrm{Pb}$ concentrations and studied by X-ray diffraction and optical microscopy. Microscale $\mathrm{Zn}$ and $\mathrm{Pb}$ distribution maps were obtained by using micro-X-ray fluorescence on thin sections. For the Cambisol, the composition, morphology and large $\mathrm{Zn}$ and $\mathrm{Pb}$ concentrations of coarse-sized F2 fractions were consistent with a geogenic metal origin. In both soils, $<20-\mu \mathrm{m}$ fractions contained the largest amounts of $\mathrm{Zn}$ and $\mathrm{Pb}$. In the Cambisol, this $<20-\mu \mathrm{m}$ fraction included poorly crystalline Mn-rich material, encouraging strong Pb sorption. The Ferralsol $<20-\mu \mathrm{m}$ fractions contained more Al- and Fe-oxide-rich microaggregates, which also enhanced strong metal retention. Large sesquioxide contents in these and similar tropical soils reduce metal mobilities. This limits the risk of toxicity when such soils, with metal contents exceeding guidelines, are used for agriculture.
\end{abstract}

\section{Introduction}

In different parts of the Central Plateau of Brazil, soils developed on dolomite limestone and metapelitic rocks display fairly large zinc $(\mathrm{Zn})$ and lead $(\mathrm{Pb})$ contents (Burak et al., 2010). These are ascribed to inheritance from hydrothermal alteration and mineralization processes associated with the formation of non-sulphide and sulphide-rich $\mathrm{Zn}-\mathrm{Pb}$ deposits in the source carbonate rock of the Vazante Group (Dardenne, 1979; Monteiro et al., 2007). These rocks are located at the west side of the São Francisco Craton, and cover an area of more than $300000 \mathrm{~km}^{2}$ (Misi et al., 2005). This stable craton consolidated during the Proterozoic to the Upper Ordovician (2.5 Ga to $450 \mathrm{Ma}$.) and has been subject to etchplanation and the formation of tablelands at current altitudes of

Correspondence: F. van Oort. E-mail: vanoort@versailles.inra.fr

Received 23 December 2011; revised version accepted 26 October 2012
900-1200 m, forming the Brazilian Central Plateau (King, 1956). Subsequent erosion during the Tertiary gave planar surfaces at altitudes of 480-750 m, with outcrops of carbonate-hosting $\mathrm{Zn}-\mathrm{Pb}$ dolomitic rocks forming positive relief features in the peneplain landscape, particularly in the Paracatu-Vazante region (Marques et al., 2004a). Such outcrops are the probable sources of $\mathrm{Zn}$ and $\mathrm{Pb}$ dissemination into the regolith during the planation of the lower surfaces. Shallow, strongly weathered Ferralitic Cambisols have developed on the dolomite outcrops, on the upper slopes of extensive gently concave Cambisol-Ferralsol toposequences (Burak, 2008; Burak et al., 2010). Ferralsols (IUSS-WRB, 2006) developed in deeply weathered metapelitic rock in foot- and toe-slope positions. The metapelitic soils contain mainly stable constituents dominated by quartz, low activity clays (kaolinite) and iron and aluminum oxides (Fontes \& Weed, 1991; Buol \& Eswaran, 2000), and exhibit a characteristic ferralitic structure of highly stable, siltand sand-sized microaggregates. 
Despite many geological and soil surveys, studies on the dynamics of $\mathrm{Zn}$ and $\mathrm{Pb}$ in the soils of the Central Plateau region are rare. However, developing agriculture and livestock farming constantly require the exploitation of new land areas, including those soils with large natural contents of heavy metals, which sometimes exceed current Brazilian guidelines (Companhia de Tecnologia de Saneamento Ambiental de Brasil, CETESB, 2005). Burak et al. (2010) reported large regional variability of metal contents in soils in an area covering more than $15000 \mathrm{~km}^{2}$, developed from different geological formations. These authors noted that $7 \%$ of 237 soil samples showed $\mathrm{Pb}$ concentrations larger than the cautionary limit for Brazilian soils $\left(72 \mathrm{mg} \mathrm{kg}^{-1}\right)$ and $3 \%$ of the samples had $\mathrm{Pb}$ concentrations larger than the intervention limit (180 $\mathrm{mg} \mathrm{kg}^{-1}$, CETESB, 2005). Such large $\mathrm{Zn}$ and $\mathrm{Pb}$ concentrations mainly occurred in soils near carbonatehosted $\mathrm{Zn}-\mathrm{Pb}$ deposits. Ferralsols occupied almost $40 \%$ of this area of about $1000 \mathrm{~km}^{2}$, whereas Cambisols on the dolomitic outcrops occupied only small areas, but are important as sources of dissemination of these metals into surrounding soils.

Insight into the origin and fate of heavy metals in soils can be obtained from their spatial distribution patterns at a micrometre scale (Semlali et al., 2001; Labanowski et al., 2007). Highly reactive metal-accumulating soil components include different forms of iron and manganese oxides and hydroxides, such as concretions, nodules, soft nodules, fine grained aggregates, mottles and coatings (McKenzie, 1989; Latrille et al., 2001; Manceau et al., 2003; van Oort et al., 2006, 2008). Such ironrich components are major constituents of soils formed under humid tropical weathering. Physical fractionation, based on the size and/or density of soil components, and subsequent chemical analysis of separated fractions can be used to study metal distributions at a microscale. These techniques differentiate metalaccumulating soil phases and compartments, such as organic and mineral components, aggregates and soil fabrics (Ducaroir \& Lamy, 1995). In combination with X-ray diffraction (XRD) and optical microscopy, techniques based on physical fractionation elucidate the constitution, micro-organization and elemental distribution patterns in soil horizons, and the incorporation and redistribution dynamics of metals.

The present work aimed to (i) examine whether $\mathrm{Zn}$ and $\mathrm{Pb}$ microscale distribution patterns in the Cambisol-Ferralsol sequence were compatible with the hypothesis of a geogenic metal origin in dolomitic limestone parent rock of the Cambisol and their dissemination into the Ferralsols and (ii) assess the role of sesquioxides in $\mathrm{Zn}$ and $\mathrm{Pb}$ retention. We selected a characteristic Cambisol-Ferralsol soil pair, based on a previous geochemical soil survey (Burak et al., 2010).

\section{Materials and methods}

\section{Study area}

The study soils were located in Paracatu-Vazante, (Minas Gerais State, Brazil), an area characterized by large soil concentrations of $\mathrm{Zn}$ and $\mathrm{Pb}$. In this region, mineralized dolomitic limestone of the Vazante Group hosts the greatest $\mathrm{Zn}-\mathrm{Pb}$ deposits in South America (Monteiro et al., 2007). The mineral reserves of the two mined deposits, Vazante and Morro Agudo, are estimated at $18 \mathrm{Mt}$ (containing mainly high-grade zinc silicate, willemite) with about $23 \% \mathrm{Zn}$ and $8 \mathrm{Mt}$ containing $6.3 \% \mathrm{Zn}$ and $2.2 \% \mathrm{~Pb}$, respectively (Teixeira et al., 2007). The tectonic setting, geological framework and mineral deposits of the Vazante Group were extensively studied by Dardenne (1979), Misi et al. (2005), and Monteiro et al. (2007). The local geomorphology and macroand meso-spatial distribution of heavy metal concentrations in soils developed on the different geological formations, including those in the Paracatu-Vazante region, were surveyed by Burak et al. (2010). In surrounding areas, Marques et al. (2004b) reported data on trace element composition in sedimentary rocks, including pelitic rocks, which showed particularly small $\mathrm{Zn}$ and $\mathrm{Pb}$ concentrations, $22 \pm 9$ and $9 \pm 6 \mathrm{mg} \mathrm{kg}^{-1}$, respectively.

Based on the survey of Burak et al. (2010), a characteristic Cambisol and Ferralsol were selected near a dolomite outcrop on a gently sloping toposequence typical of the Paracatu-Vazante landscape. The Ferralitic Cambisol $\left(17^{\circ} 01^{\prime} 28.9^{\prime \prime} \mathrm{S}, 46^{\circ} 49^{\prime} 12.1^{\prime \prime} \mathrm{W}\right)$ is on the colluvial back-slope of the dolomite outcrop and the Rhodic Ferralsol is on metapelitic rocks, located about $260 \mathrm{~m}$ downslope. The difference in altitude between the two soils was only a few metres and the ruling gradient is $2-3 \%$. The toposequence was located in the Cerrado biome. The Cambisol was formerly under seasonally deciduous forest, typical of limestone outcrops, and the Ferralsol under more open Cerrado woodland. Nowadays both soils are under extensive pasture (Brachiaria decumbens Stapf.). The climate is tropical humid (Aw, Köppen classification) with mean annual temperature of $22-23{ }^{\circ} \mathrm{C}$ and precipitation of about $1450 \mathrm{~mm}$. Surface, transitional and subsoil horizons were described in large soil pits, and bulk samples of several kilograms were collected from all horizons, airdried, sieved to $<2 \mathrm{~mm}$ and stored before analyses. Undisturbed samples were collected for preparation of thin sections.

\section{Soil analyses}

Total metal element concentrations in samples were determined in three replicates after two stages of microwave digestion of $0.5 \mathrm{~g}$ sample with $9 \mathrm{ml}$ concentrated $\mathrm{HNO}_{3}$ and $3 \mathrm{ml}$ concentrated $\mathrm{HF}$, first with a progressive temperature increase up to $170{ }^{\circ} \mathrm{C}$ at maximum power of $350 \mathrm{~W}$ for 15 minutes and then at $180{ }^{\circ} \mathrm{C}$ for 5 minutes (Fernandez et al., 2008) using a MarsXpress microwave oven (CEM corporation, Matthews, NC, USA). Diethylene triaminopentaacetic acid (DTPA) extraction was used to determine the available fractions of the metals (Lindsay \& Norvell, 1978). Concentrations of $\mathrm{Zn}$ and $\mathrm{Pb}$ were determined by flame atomic absorption spectroscopy (FAAS 220, Varian, Mulgrave, Victoria, Australia) and concentrations of aluminium $(\mathrm{Al})$, iron $(\mathrm{Fe})$ and manganese $(\mathrm{Mn})$ by inductively coupled plasma atomic emission spectrometry (ICP-AES, Perkin-Elmer Optima 3300 TV; Perkin-Elmer, Norwalk, CT, USA). The accuracy of the analytical determinations was verified by assaying certified 
reference samples: Buffalo River Sediment (SRM 2704), San Joaquin Soil (SRM2 700), Lake Sediment (LKSD-1) (NIST, Gaithersburg, MD, USA) and CRM 7001 (CMI, Prague, Czech Republic), after tri-acid digestion in a microwave oven.

The clay fractions of bulk samples of the two soils were extracted after chemical dispersion. The proportions of kaolinite and gibbsite were quantified by thermo-gravimetric analysis (TGA) with a Netzsch-STA-409 apparatus (Netzsch, Selb, Germany). The amounts of free and amorphous Fe and Mn were determined after extractions with dithionite-citrate-bicarbonate (DCB, Mehra \& Jackson, 1960) and ammonium oxalate (McKeague \& Day, 1966), respectively.

\section{Physical fractionation and analyses}

Size fractionations of carefully quartered, $<2$-mm subsamples of bulk soil horizon samples were carried out in water to study the mass distribution of $\mathrm{Zn}$ and $\mathrm{Pb}$ in different soil size fractions. No chemical dispersants were added, in order to minimize redistribution of metal elements. Fifty grams of soil were dispersed by agitation for 16 hours in $180 \mathrm{ml}$ water with glass beads, as described by Balesdent et al. (1991) and Ducaroir \& Lamy (1995). The resulting suspension was sieved to separate four sizefractions: 200-2000, 50-200, 20-50 and $<20 \mu \mathrm{m}$, referred to as Fractionation 1 (F1) (Figure 1). The $<20-\mu \mathrm{m}$ fraction included the fine silt and clay fractions, and was studied here as one entity. This choice was linked to the strong micro-aggregation of these size classes in the strongly weathered soils, resulting from the presence of bonding sesquioxides and flocculation by large amounts of trivalent cations. This makes the separation of fine silt and clay impossible without the use of chemical dispersants.

In a second step of the fractionation, a portion of each of the F1 $>20-\mu \mathrm{m}$ fractions was dispersed ultrasonically with Deltasonic1320 equipment (Aerosec, Fécamp, France) for 45 minutes at $28 \mathrm{kHz}$, corresponding to $500 \mathrm{~J} \mathrm{ml}^{-1}$ power. The disaggregated material was then recovered on a $20-\mu \mathrm{m}$ mesh sieve. Thus, a second series (F2) of fractions were produced: 200-2000, 50-200 and $20-50 \mu \mathrm{m}$ and three related recovered $\mathrm{F} 2<20-\mu \mathrm{m}$ fractions (Figure 1).

Within the F2 200-2000- $\mu \mathrm{m}$ sand fraction, an additional separation was performed by sieving at $1000 \mu \mathrm{m}$. The four dominant minerals of rounded quartz, irregular silcrete, micaceous sand grains and iron-manganese nodules were distinguished, from their morphology, colour, shine and size in the 1000-2000$\mu \mathrm{m}$ fraction, and collected by handpicking under a binocular microscope. Their proportional mass-percentages were calculated with respect to the total mass of the 1000-2000- $\mu$ m fraction. Total element concentrations in each of the fractions were determined by the same methods as for bulk soil.

Mineralogical analyses were performed by XRD on ground powder samples of the F2 20-50- $\mu \mathrm{m}$, of the F2 $<20 \mu \mathrm{m}$ derived from the F1 20-50- $\mu \mathrm{m}$ fractions of B horizons of both soils, and of the 1000-2000- $\mu \mathrm{m}$ handpicked minerals, using D5000-Kristalloflex equipment (Siemens, Karlsruhe, Germany), with $\mathrm{Co}-\mathrm{K} \alpha$ radiation and operating at $40 \mathrm{kV}, 30 \mathrm{~mA}$. Disaggregation and effectiveness of ultrasonic treatment for the silt and sand fractions was controlled with a Wild M3Z binocular microscope with a resolution of 35-400 X (Wild, Heerbrugg, Switzerland), coupled to an Olympus digital camera (Olympus, Tokyo, Japan).

\section{Micromorphology and $\mu-X R F$ of undisturbed soil thin sections}

Undisturbed samples were collected in hard cardboard boxes $(7 \times 7 \mathrm{~cm})$ and impregnated under vacuum in a polyester resin. One thin section of $30-\mu \mathrm{m}$ thickness was prepared for each horizon, according to the methods of FitzPatrick (1970), with a polyester resin 'Synolith 544' (Euroresins Benelux BV, Budel, the Netherlands). The nature, morphology and micro-fabrics of soil constituents were studied with a petrographic Nikon Eclipse E400 polarizing light microscope (Nikon, Tokyo, Japan) using

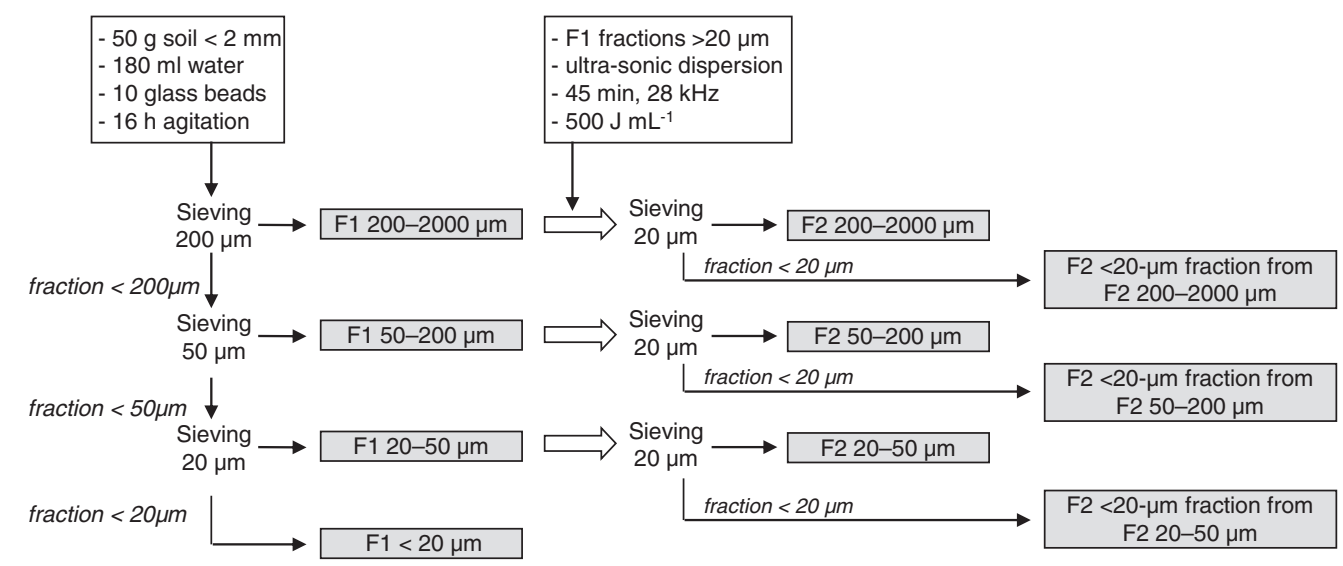

FRACTIONATION 1

Figure 1 Physical fractionation scheme used for the separation of granulometric size-fractions $200-2000,50-200,20-50$ and $<20-\mu \mathrm{m}$ fractions, before (F1) and after (F2) dispersive ultrasonification. 
the terminology of Stoops (2003). Elemental mapping by $\mu$-XRF was performed with a RU-200B rotating anode X-ray generator (Rigaku Corporation, Tokyo, Japan) at the LAPA laboratory of the Centre d'Études Atomiques (CEA, Saclay, France) on selected areas of soil thin sections. The beam delivered by a molybdenum anode (main $\mathrm{K} \alpha$ at $17.5 \mathrm{keV}$ ) was monochromatized, providing a $\mathrm{K} \alpha$ spectral purity $>97 \%$ and $\mathrm{K} \beta$ contamination $<0.3 \%$. Beam focusing with a spot size of $50 \times 30 \mu \mathrm{m}$ at the surface of samples was performed with a FOX D Mo 25-25P (Xenocs, Grenoble, France) collimating multilayer optics system. Runs were made at $21 \mathrm{~mA}$ and $55 \mathrm{kV}$ and dwell times of 300 or $530 \mathrm{~s}$ per point. Samples were placed at $45^{\circ}$ of the X-ray beam and fluorescence spectra were collected at $90^{\circ}$ through an AXAS Vitus SDD (10 $\mathrm{mm}^{2}$ of active surface) Ketek detector (Ketek, München, Germany). An in-house program in Visual Basic 6.0 was used to synchronize the samples' displacement (step size $\Delta \mathrm{x}=50 \mu \mathrm{m}$, $\Delta \mathrm{z}=30 \mu \mathrm{m}$, but $\Delta \mathrm{y}=0$ is along the $\mathrm{X}$-ray beam) with motorized linear translation stages (M-UTM series by Micro-Controle ${ }^{\odot}$, Newport Spectra-Physics, Evry, France) and the spectra acquisition recorded with a GENIE-2000 program $\left(\right.$ Canberra $^{\odot}{ }^{\circ}$, Canberrea france, Montigny-le-Bretonneuax, France). Finally, elemental distribution maps were generated using Origin ${ }^{\circledR}$ (Microcal Software Inc., Northampton, MA, USA).

\section{Results}

\section{Macro-morphology}

The shallow Cambisol had a clay loam fine earth texture throughout, with rock fragments occurring mainly below $40 \mathrm{~cm}$ (Table 1). The A horizon displayed a weak to moderate medium subangular blocky structure, becoming weak to moderate fine subangular blocky in the sub-surface horizons. The Ferralsol was deeply weathered with a clay texture. The A horizon showed a moderate fine subangular blocky structure, and a fine to very fine granular microstructure, typical for Ferralsols, was observed only in the Bo2 and Bo3 horizons. Soil colour varied little between horizons, but Bo horizons had larger chroma values, concomitant with the largest iron contents.

\section{Chemical features of bulked soils}

Both soils were slightly acid in the topsoil and more acid at depth (Table 1), and had about $1 \%$ organic carbon in the surface horizons, which decreased rapidly with depth, notably to $0.1-0.2 \%$ in the Ferralsol Bo horizons. Total Mn contents in the Cambisol were about three- to four-fold larger than in the Ferralsol. Total and DTPA-extractable concentrations of Mn, $\mathrm{Zn}$ and $\mathrm{Pb}$ were generally larger in the Cambisol than in the Ferralsol (Table 1). Total $\mathrm{Zn}$ and $\mathrm{Pb}$ concentrations varied little between the surface and deeper horizons in both soils. This remarkable consistency of total contents of trace metals with depth suggests negligible anthropogenic metal inputs. Concentrations of DTPA-extractable $\mathrm{Zn}$ and $\mathrm{Pb}$ were largest in the A horizons, suggesting metal binding by organic matter. In sub-surface horizons, variations of the DTPA/total ratios for $\mathrm{Zn}$ and $\mathrm{Pb}$ were small, notably in deeper Bo horizons of the Ferralsol (Zn, about $0.1 \% ; \mathrm{Pb}, 1.6-2.3 \%)$. Large concentrations of DTPA-extractable $\mathrm{Mn}$ in the Cambisol (150-200 $\mathrm{mg} \mathrm{kg}^{-1}$ ) contrasted with small values in the Ferralsol $\left(0.85-13 \mathrm{mg} \mathrm{kg}^{-1}\right)$.

Table 2 shows the amounts of kaolinite and gibbsite and the concentrations of free and amorphous $\mathrm{Fe}$ and $\mathrm{Mn}$, determined on clay fractions that were additionally extracted after chemical dispersion. The Ferralsol had larger amounts of kaolinite, increasing to about $60 \%$ in the Bo horizons, but proportions of gibbsite were similar (about $8-10 \%$ ) in both soils. These mineralogical data underline the highly weathered character of the Ferralsols. Larger DCB-extractable Fe concentrations were found in the Ferralsol, but DCB-Mn concentrations in the Cambisol were about two-fold larger than in the Ferralsol. The oxalate-extractable Fe concentrations were small $(\leq 2 \%$, Table 2$)$ but the amount of oxalate-extractable $\mathrm{Mn}$ was important in the Cambisol: about $65-70 \%$ of free $\mathrm{Mn}$ was present as amorphous compounds.

Based on soil structure and geochemical consistency with depth, we selected the surface Ap horizons of both profiles, the Cambisol $\mathrm{Bw}$ and Ferralsol Bo2 horizons, for a detailed study of $\mathrm{Zn}$ and $\mathrm{Pb}$ distributions.

\section{Size fractions}

Distribution. The distribution of size fractions obtained by the F1 physical fractionation in water showed that the $<20-\mu \mathrm{m}$ fraction was the largest (40-55\%) in both soils, with Bo2Ferral> ApFerral $>$ BwCamb $>$ ApCamb (Figure 2). The contributions from the coarser fractions decreased with increasing size, from coarse silt $(25-30 \%)$ to coarse sand $(7-10 \%)$. These results from dispersion in water slightly diverge from the soil texture data in Table 1, the latter being obtained after chemical dispersion. Sonification produced only small decreases in the F1 200-2000, $50-200$ and $20-50-\mu \mathrm{m}$ fractions of all horizons. Adding the dispersed $\mathrm{F} 2<20-\mu \mathrm{m}$ material to the $\mathrm{F} 1<20-\mu \mathrm{m}$ fraction increased the overall $\mathrm{F} 1+\mathrm{F} 2<20-\mu \mathrm{m}$ fraction by $3-10 \%$. Sonification was proportionately most effective for the small F1 $20-50-\mu \mathrm{m}$ fraction of the Ferralsol Bo2 horizon (Figure $2 \mathrm{~b}$ ), with about $30 \%$ recovered in the $\mathrm{F} 2<20-\mu \mathrm{m}$ fraction.

Mineralogical composition. Four main types of sand particles were distinguished optically in the $1000-2000-\mu \mathrm{m}$ fraction of both soils (Figure 3). Their nature was established by XRD (Figure 4a) and optical microscopy: transparent rounded quartz grains (Figures 3a, 4a, spectrum A), quartz as silcrete (Figures 3b, $4 \mathrm{a}$, spectrum B), micaceous sand grains (Figures 3c, 4a, spectrum C) and iron-manganese concretions (Figures 3d, 4a, spectrum D). Hematite and quartz were observed in iron concretions, and mica and quartz in micaceous sands. Quartz occurred as transparent, rounded grains and as more angular, irregular silcrete, and accounted for $88-98 \%$ of the $1000-2000-\mu \mathrm{m}$ fraction. Sand-sized iron-manganese concretions and micaceous minerals were present in minor amounts. These minerals were more 


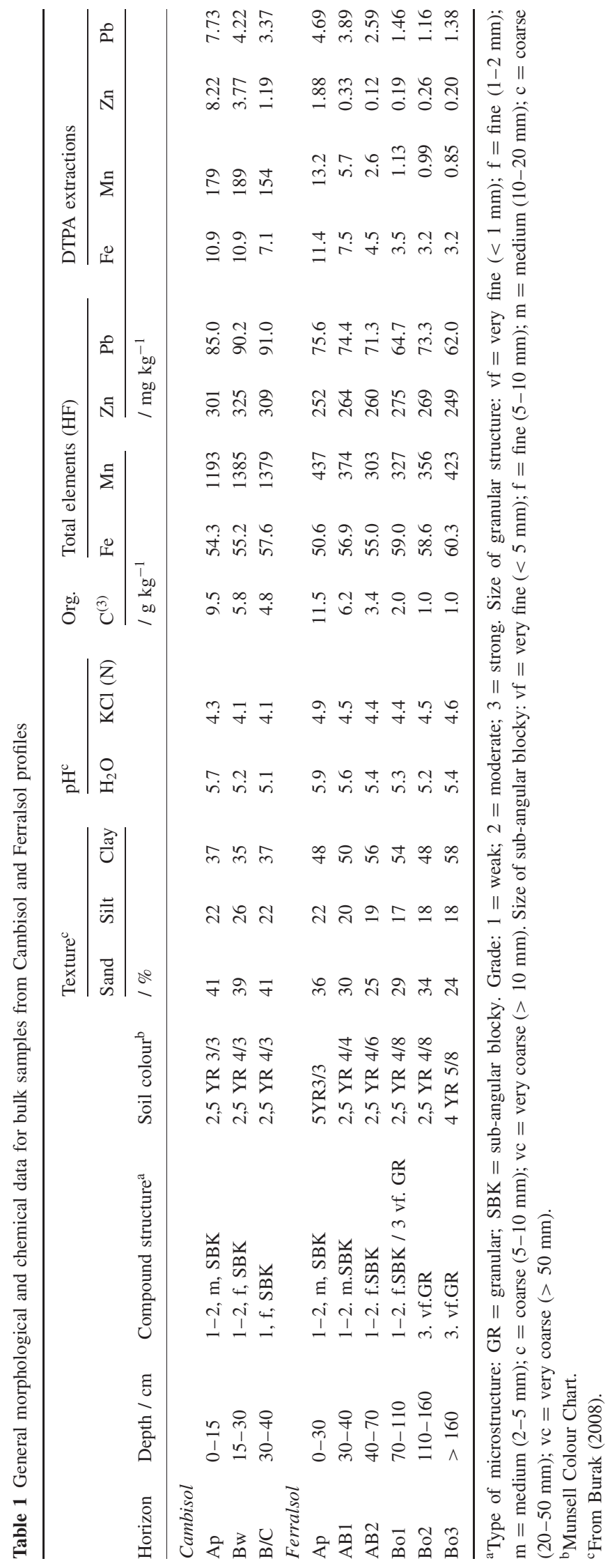


Table 2 Quantitative mineralogical composition from thermal gravimetric analyses (TGA), and dithionite-citrate-bicarbonate (DCB) and ammonium-oxalate extractable Fe and Mn concentrations, determined on separated $<2-\mu \mathrm{m}$ fractions in horizons of the study soils (modified after Burak, 2008)

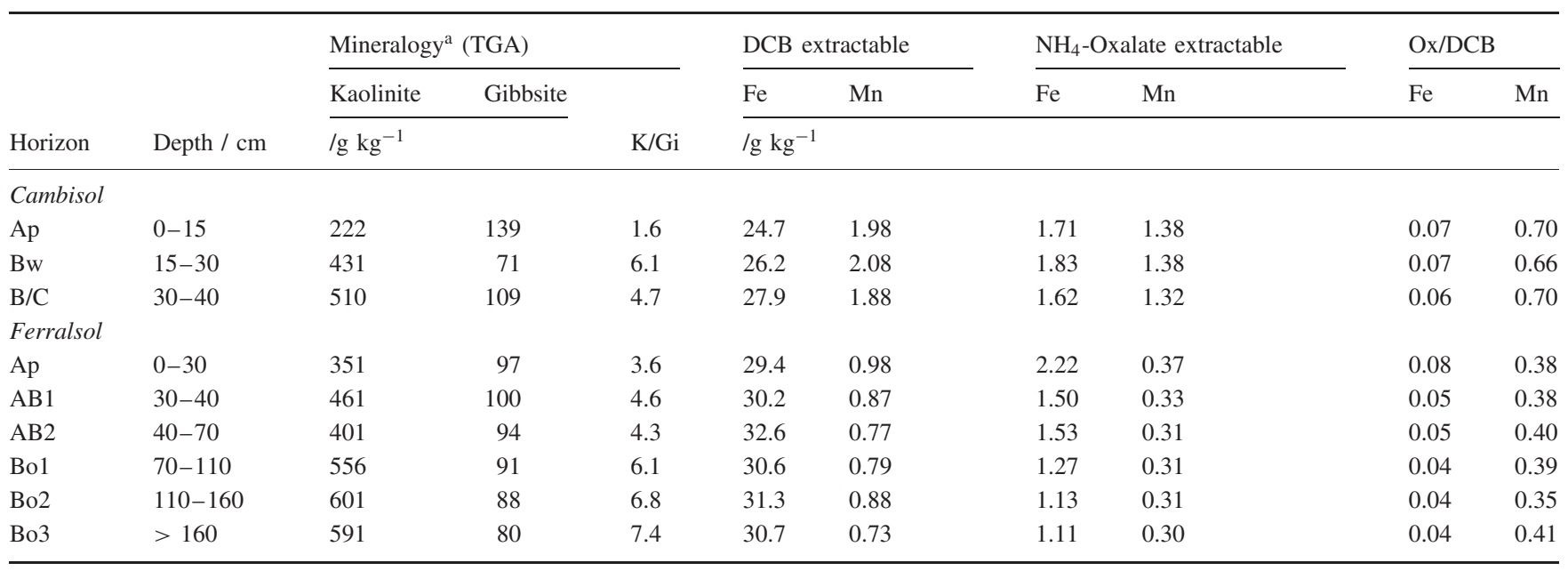

${ }^{\mathrm{a}}$ After DCB treatment.
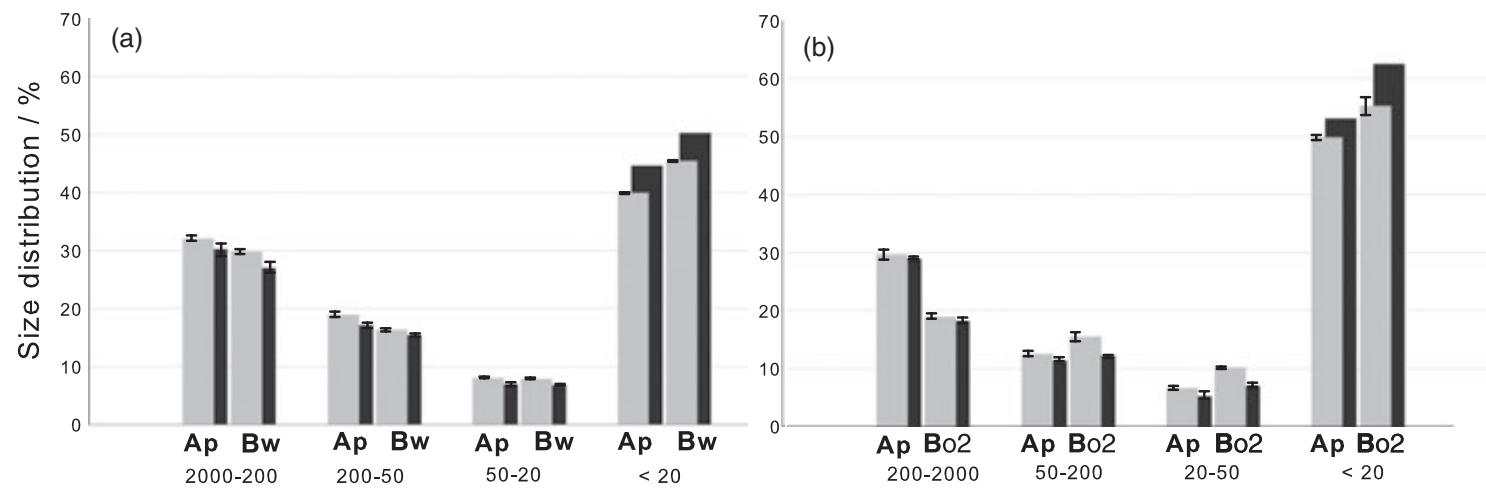

Size fractions $/ \mu \mathrm{m}$

Figure 2 Distribution of granulometric size classes obtained by physical fractionation in water of samples from A and B horizons of the Cambisol (a) and Ferralsol (b). The F2 $<20-\mu \mathrm{m}$ fraction represents the pooled F1 $+3 \times \mathrm{F} 2<20-\mu \mathrm{m}$ fractions. F1 (grey), before ultrasonification; F2 (black), after ultrasonification.

abundant in the Cambisol (about 5\%) and were only occasionally observed in the Ferralsol. In the Cambisol, the iron oxide fraction included a consistent proportion of coarse-sized, iron pseudomorphs after cubic crystal clusters (Figure 3e), which were probably the alteration products of sulphide metal ores such as galena, sphalerite or pyrite. Hematite inclusions were observed in the rounded quartz grains (Figure 3f), indicative of hydrothermal events (Binns, 2006), but not in the pedogenic silcrete.

Effects of ultrasonification on the $20-50-\mu \mathrm{m}$ fractions, checked under the optical microscope and by XRD, were similar for all samples. Sonification of the Bw horizon of the Cambisol caused the disappearance of dark reddish-brown colouration (Figure 3g-i). This is ascribed to the removal from the F1 20-50$\mu \mathrm{m}$ fraction of $\mathrm{Fe}-\mathrm{Mn}$-rich mineral material: oxide-precipitates on quartz grains, micronodules and/or microaggregates (Figure 3h). In the Bo2 of the Ferralsol, rounded, orange to reddish lightcoloured microaggregates were less abundant after sonification (Figure $3 \mathrm{j}-1$ ).
The XRD patterns indicated predominant quartz in the $\mathrm{F} 2$ $20-50-\mu \mathrm{m}$ fraction (Figure $4 \mathrm{~b}$, spectra A, C). In the F2 $<20-\mu \mathrm{m}$ fraction, recovered from the $\mathrm{F} 120-50-\mu \mathrm{m}$ fractions, only traces of quartz were found, mica and kaolinite were detected in both soils, goethite and gibbsite were detected only in the Ferralsol, but no hematite was found (Figure 4b, spectra B, D).

$\mathrm{Zn}$ and $\mathrm{Pb}$ concentrations. Total $\mathrm{Zn}$ and $\mathrm{Pb}$ concentrations measured in both the F1 and F2 fractions (Figure 5) were generally larger in the Cambisol than in the Ferralsol, notably for coarse fractions. The largest concentrations were found in $<20-\mu \mathrm{m}$ fractions for both soils. For $\mathrm{Zn}$, the concentrations of the $<20$ $\mu \mathrm{m}$ fraction varied from about $600 \mathrm{mg} \mathrm{kg}^{-1}$ in the Cambisol to about $350 \mathrm{mg} \mathrm{kg}^{-1}$ in the Ferralsol. Concentrations of $\mathrm{Pb}$ varied less, and ranged between $180 \mathrm{mg} \mathrm{kg}^{-1}$ in the Cambisol and $140 \mathrm{mg} \mathrm{kg}^{-1}$ in the Ferralsol.

After ultrasonification, metal concentrations decreased consistently in $>20-\mu \mathrm{m}$ fractions, indicating that $\mathrm{Zn}$ and $\mathrm{Pb}$ were mostly 

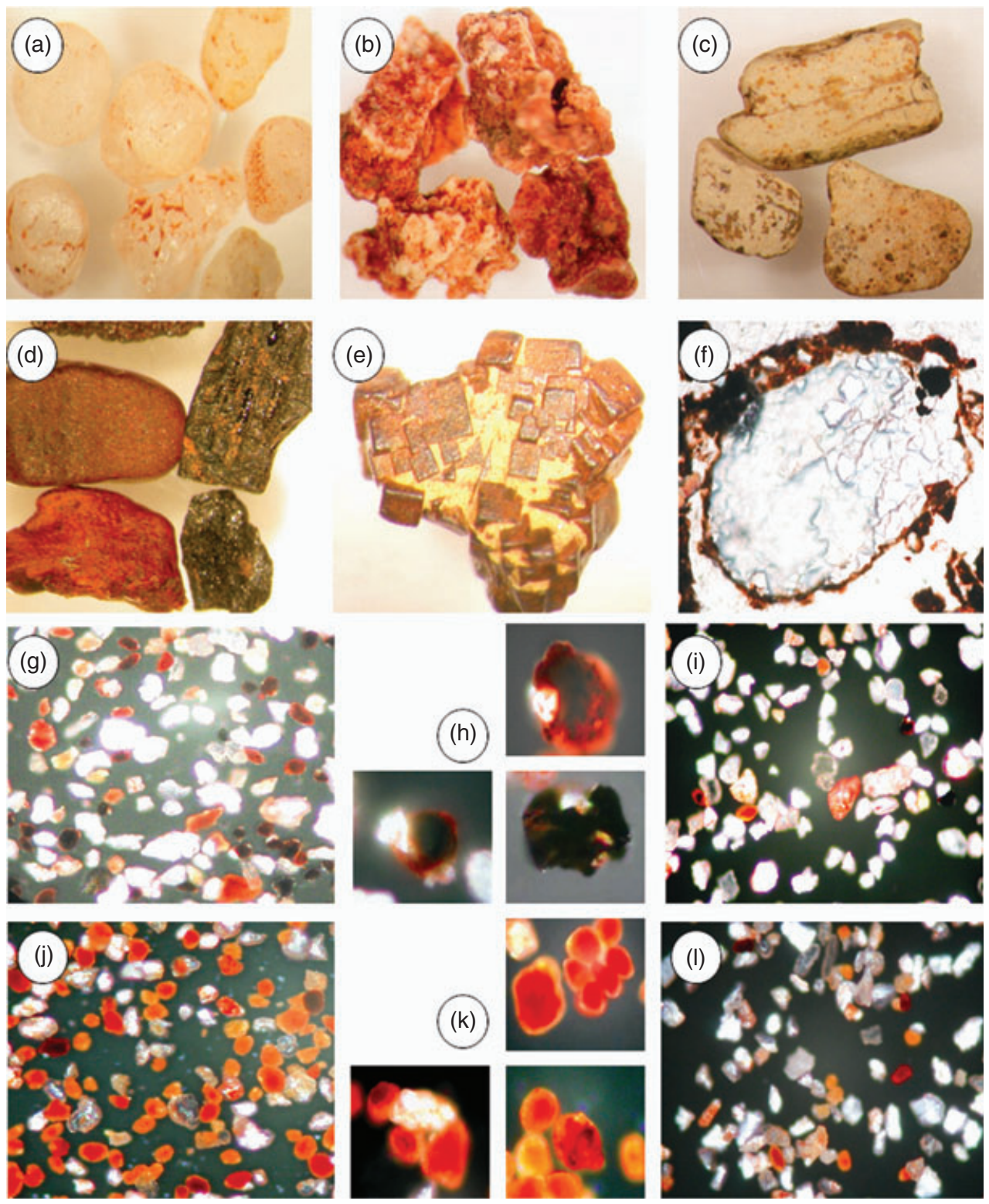

Figure 3 Optical microscope images. (a)-(f) Main types of mineral particles occurring in the 1000-2000- $\mu$ m fractions of the Cambisol and Ferralsol, isolated by handpicking: (a) transparent rounded quartz, (b) silcrete, (c) micaceous sand grains, (d) iron and manganese oxide particles, (e) iron-oxide pseudomorph after cubic crystal cluster, present in the Cambisol, (f) quartz with hematite inclusion. (g)-(l) Microphotographs of effects of ultrasonification on the 20-50- $\mu \mathrm{m}$ fractions. Cambisol Bw horizon: (g) F1 20-50- $\mu \mathrm{m}$ fraction, (h) pedofeatures in dispersed F2 $<20-\mu \mathrm{m}$ derived from the F1 20-50- $\mu \mathrm{m}$ fraction, (i) F2 20-50- $\mu \mathrm{m}$ fraction. Ferralsol Bo2 horizon: (j) F1 20-50- $\mu \mathrm{m}$ fraction, (k) pedofeatures in dispersed F2 $<20-\mu \mathrm{m}$ derived from the F1 20-50- $\mu \mathrm{m}$ fraction, (1) F2 20-50- $\mu \mathrm{m}$ fraction.

recovered in $<20-\mu \mathrm{m}$ dispersible soil material. This effect was less important for the Cambisol than for the Ferralsol. In particular, $\mathrm{Pb}$ concentrations of the Cambisol B F2 residual $>20-\mu \mathrm{m}$ fractions were clearly larger than in comparable Ferralsol Bo2 fractions (Figure 5c,d). Clear effects of ultrasonification were also observed for the Ferralsol $20-50-\mu \mathrm{m}$ fractions, with $\mathrm{Zn}$ decreasing from (F1) $98-185$ to (F2) 5-44 $\mathrm{mg} \mathrm{kg}^{-1}$ (Figure 5b) and with $\mathrm{Pb}$ decreasing from about (F1) 100 to (F2) $9-35 \mathrm{mg} \mathrm{kg}^{-1}$ (Figure 5d).
Concentrations of $\mathrm{Zn}$ and $\mathrm{Pb}$ in the F2 1000-2000- $\mu \mathrm{m}$ fractions were generally larger in the Cambisol than in the Ferralsol (Table 3), but showed large differences between the different minerals: very small for rounded quartz, small for silcrete minerals and large for micaceous sand grains in the Cambisol $\left(250 \mathrm{mg} \mathrm{kg}^{-1} \mathrm{Zn}\right.$ and $120 \mathrm{mg} \mathrm{kg}^{-1} \mathrm{~Pb}$ ). There was very little unweathered micaceous sand in the Ferralsol (insufficient material for analyses of $\mathrm{Zn}$ and $\mathrm{Pb}$ ). Very large concentrations were observed in $\mathrm{Fe}$ Mn-concretion sand grains in the Cambisol, notably for the 

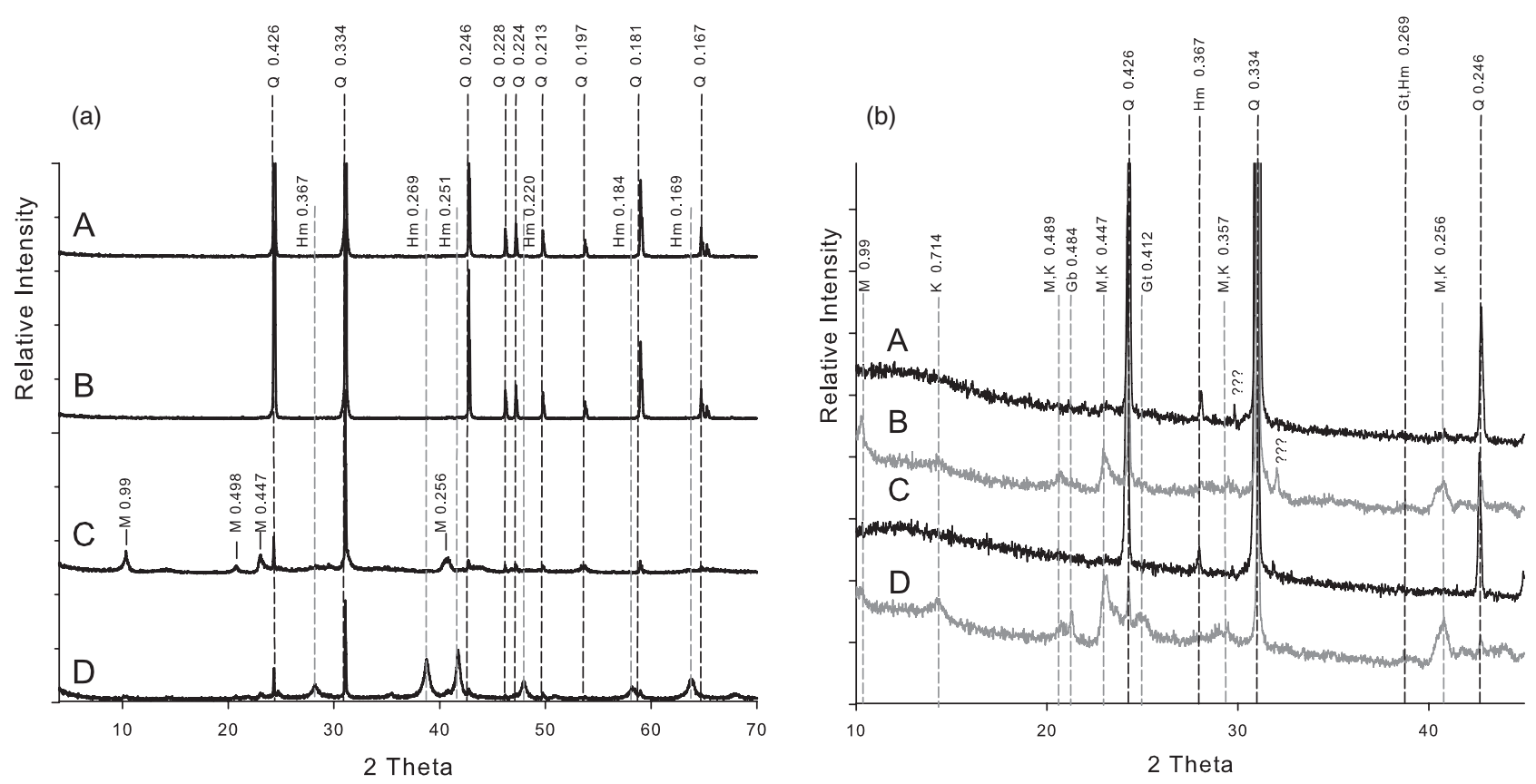

Figure 4 (a) X-ray diffraction patterns of the mineral particle fractions shown in Figure 3a-d. A, transparent rounded quartz; B, silcrete; C, micaceous sand grains; D, iron and manganese oxide particles. (b) X-ray diffraction patterns of F2 20-50- $\mu \mathrm{m}$ fractions of the Cambisol Bw horizon (A) and the Ferralsol Bo2 horizon (C) and of F2 $<20-\mu \mathrm{m}$ fractions of these two fractions for the Cambisol Bw horizon (B) and the Ferralsol Bo2 horizon (D). d-spacings in $\mathrm{nm} ; \mathrm{K}=$ Kaolinite; $\mathrm{M}=$ Mica; $\mathrm{Gb}=$ Gibbsite; $\mathrm{Hm}=$ Hematite; $\mathrm{Gt}=$ Goethite; $\mathrm{Q}=$ Quartz.

cubic crystal pseudomorphs (approximately $2200 \mathrm{mg} \mathrm{kg}^{-1} \mathrm{Zn}$, $1140 \mathrm{mg} \mathrm{kg}^{-1} \mathrm{~Pb},>7500 \mathrm{mg} \mathrm{kg}^{-1} \mathrm{Mn}$ and more than $50 \% \mathrm{Fe}$ ). Such concentrations were about twice those observed in undifferentiated sand-sized iron-oxide grains collected for the Ferralsol.

Enrichment factors. Concentrations of $\mathrm{Zn}$ and $\mathrm{Pb}$ in $\mathrm{F} 2<20$ $\mu \mathrm{m}$ fractions, recovered from $\mathrm{F} 1>20-\mu \mathrm{m}$ fractions, were compared with those of the F1 $<20-\mu \mathrm{m}$ fractions (Table 4). Such enrichment factors (EF) were defined as $\mathrm{F} 2_{(<20 \mu \mathrm{m}) X} / \mathrm{F} 1_{(<20 \mu \mathrm{m})}$, where $X$ refers to $200-2000,50-200$ or $20-50-\mu \mathrm{m}$ fractions. The concentrations in the $\mathrm{F} 2<20-\mu \mathrm{m}$ fractions varied little for $\mathrm{Zn}$ (323-483 $\mathrm{mg} \mathrm{kg}^{-1}$ ) for both soils. Lead concentrations varied more, from $172 \mathrm{mg} \mathrm{kg}^{-1}$ in the Ferralsol to $427 \mathrm{mg} \mathrm{kg}^{-1}$ in the Cambisol. Such concentrations tended to increase when F2 $<20-\mu \mathrm{m}$ fractions were recovered from coarse and fine sand and from silt fractions. Metal concentrations in recovered F2 $<20$ $\mu \mathrm{m}$ fractions were generally larger than for the $\mathrm{F} 1<20-\mu \mathrm{m}$ fraction $(\mathrm{EF}>1)$, except for $\mathrm{Zn}$ concentrations in the Cambisol $(0.6<\mathrm{EF}<0.8)$. The $\mathrm{EF}$ was generally larger for $\mathrm{Pb}$ than for $\mathrm{Zn}$, and varied from 1.1 to 2.5 for $\mathrm{Pb}$ in the Cambisol and from 1.1 to 2.6 in the Ferralsol. The EF $\left(\mathrm{F} 2_{(<20 \mu \mathrm{m}) X} /\right.$ total bulk soil concentration) ranged from 2.0 to 4.3 for $\mathrm{Pb}$ in the Cambisol and 2.2-5.1 in the Ferralsol. For Zn, this EF ranged from 0.9 to 1.4 in the Cambisol and from 1.3 to 1.8 in the Ferralsol.

Amounts of $\mathrm{Zn}$ and $\mathrm{Pb}$ in size fractions. The contributions to the total soil contents of $\mathrm{Zn}$ and $\mathrm{Pb}$ from the $<20-\mu \mathrm{m}$ fractions represented about $80-95 \%$ of $\mathrm{Zn}$ and $\mathrm{Pb}$ (Figure 6), except for
$\mathrm{Pb}$ in the Cambisol $\mathrm{Bw}$ horizon, underlining the role of this fine fraction as a major metal-accumulating component of tropical soils. There was $10-15 \%$ of the $\mathrm{Zn}$ and $>25 \%$ of the $\mathrm{Pb}$ in the F2 $>20-\mu \mathrm{m}$ fractions in the Cambisol, indicating that dispersible forms in sand and coarse silt fractions were important metal sources. For the Ferralsol, proportions were less, 6-8\% for $\mathrm{Zn}$ and $5-7 \%$ for $\mathrm{Pb}$. Proportions of metals in dispersed microaggregated $\mathrm{F} 2<20-\mu \mathrm{m}$ fractions were $6-7 \% \mathrm{Zn}$ and $10-11 \% \mathrm{~Pb}$ in the Cambisol and 7-13\% $\mathrm{Zn}$ and $12-15 \% \mathrm{~Pb}$ in the Ferralsol. Proportions of total $\mathrm{Zn}$ in $\mathrm{F} 2<20-\mu \mathrm{m}$ fractions of $\mathrm{Bo} 2$ of the Ferralsol were up to two times larger than comparable fractions of other horizons.

\section{Metal distribution patterns determined by $\mu-X R F$ on undisturbed soil samples}

Thin sections of the $\mathrm{Bw}$ horizon of the Cambisol showed a porphyric pattern (Stoops, 2003), with coarse grains of quartz, micaceous sand and Fe/Mn-iron oxides embedded in a reddish fine-textured, micro-aggregated groundmass (Figure 7a). Frequently, thin coats of $\mathrm{Fe}$ and $\mathrm{Mn}$ oxide-rich material were observed on skeleton grains. Micro-XRF mappings of Mn, Fe, $\mathrm{Zn}$ and $\mathrm{Pb}$ distributions in a $1.5 \times 1.0-\mathrm{mm}$ area of the thin section showed similar distribution patterns for $\mathrm{Mn}$ and $\mathrm{Pb}$, with localized occurrences, whilst distributions of $\mathrm{Fe}$ and $\mathrm{Zn}$ were more diffuse (Figure $7 \mathrm{~b}$ ). The distribution of $\mathrm{Pb}$ coincided with black opaque sand- or coarse silt-sized Mn-oxide particles (Figure 7a), whereas $\mathrm{Fe}$ and $\mathrm{Zn}$ distributions corresponded 


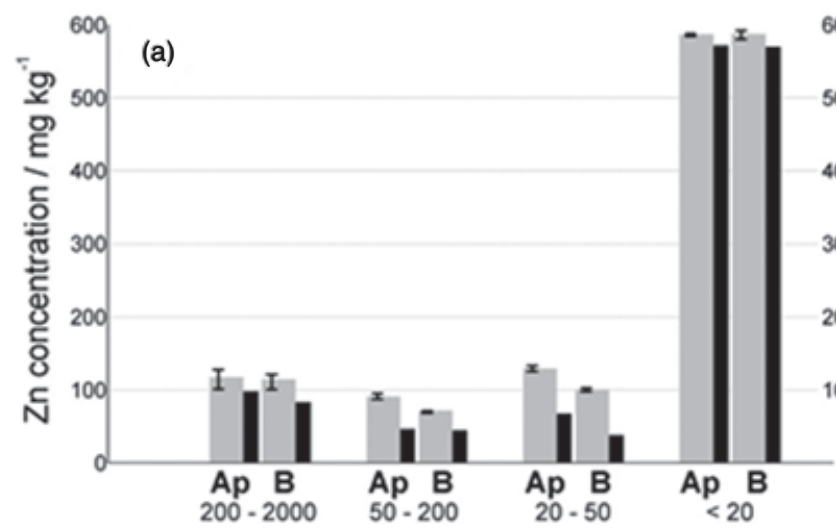

(b)
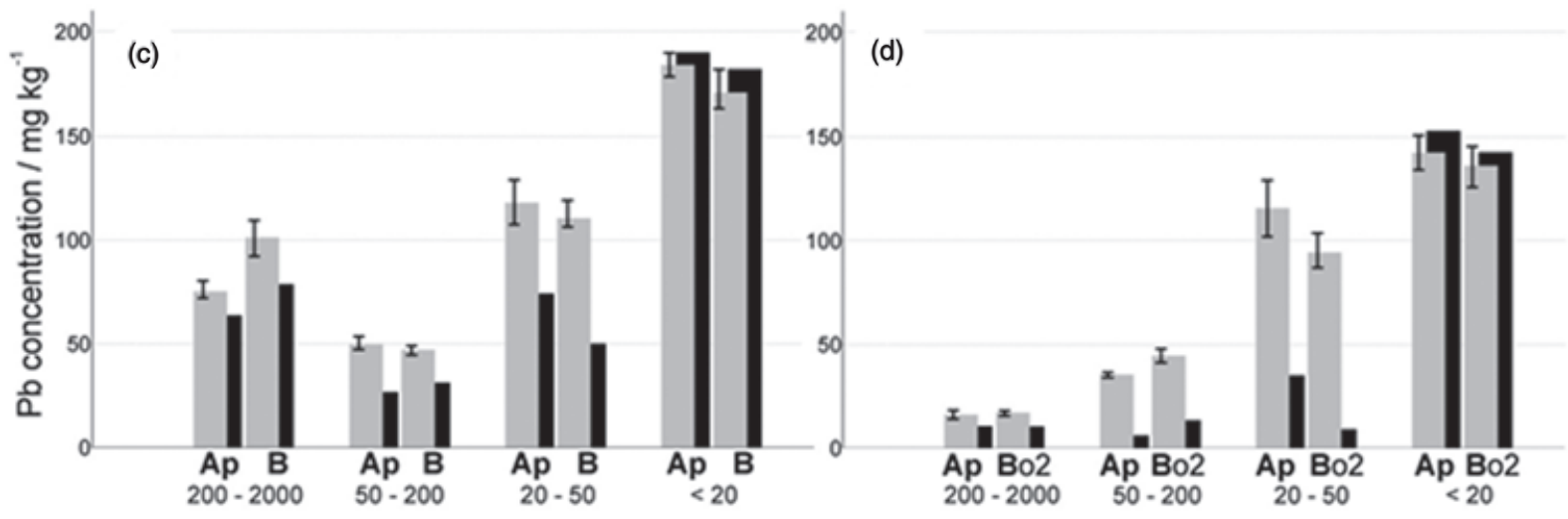

Size fractions $/ \mu \mathrm{m}$

Figure 5 Distribution of $\mathrm{Zn}$ and $\mathrm{Pb}$ concentrations in size classes obtained after physical fractionation in water of samples from A and B horizons. (a) $\mathrm{Zn}$ Cambisol, (b) Zn Ferralsol, (c) Pb Cambisol, (d) Pb Ferralsol. F1, before ultrasonification; F2, after ultrasonification.

Table 3 Concentrations of $\mathrm{Al}, \mathrm{Fe}, \mathrm{Mn}, \mathrm{Pb}$ and $\mathrm{Zn}^{\mathrm{a}}$ in different minerals separated manually from the F2 1000-2000- $\mu \mathrm{m}$ sand fractions (see also Figure 3)

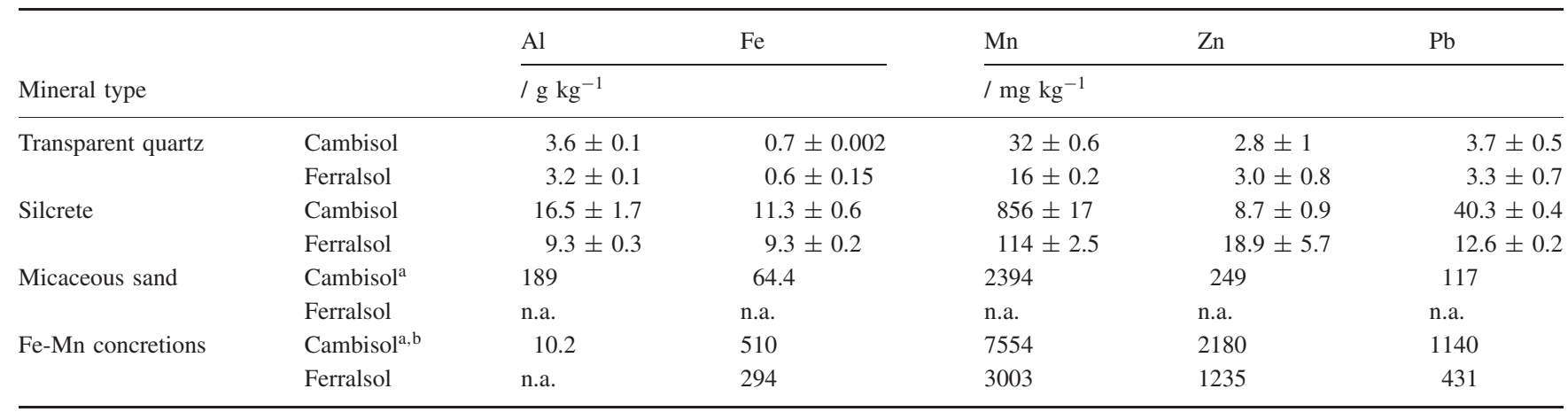

${ }^{a}$ Because of their low mass, only a single analysis of elements was made for micaceous sand grains and iron-manganese concretions.

${ }^{b}$ For the Cambisol, the analyses correspond to handpicked grains of pseudomorphs after cubic crystal clusters.

n.a. $=$ not analysed.

mainly to the micro-aggregated fine groundmass. The correlation coefficients for the surface analysed between $\mathrm{Pb}$ and $\mathrm{Mn}$, and between $\mathrm{Zn}$ and $\mathrm{Fe}$, were both $r=0.75$ (Figure 7c) $(n=$ 1054, $P<0.0001)$. Additional mapping of a $1.0 \times 0.6-\mathrm{mm}$ area, centred on an iron pseudomorph after a cubic crystal cluster (Figure 7d,e), clearly demonstrated the concurrence of Fe, Zn and $\mathrm{Pb}$ in such particles, illustrated by large correlation coefficients: $r_{\mathrm{Zn} / \mathrm{Fe}}=0.944 ; r_{\mathrm{Pb} / \mathrm{Fe}}=0.954$ (Figure 7f) $(n=441, P<0.0001)$.
There was little Mn in this pseudomorph, but it did occur at localized spots in the groundmass, usually with moderate amounts of $\mathrm{Pb}$, but the overall $\mathrm{Pb} / \mathrm{Mn}$ correlation was poor $(r=0.3)$.

The Ferralsol Bo2 horizon also had a porphyric pattern, but with large quartz grains and iron nodules embedded in a fine textured groundmass composed of iron/clay-rich microaggregates and silt-sized quartz fragments (Figure 8a). Micro-XRF on a selected $1.0 \times 1.0-\mathrm{mm}$ area showed a distinct distribution pattern 
Table 4 Concentrations of $\mathrm{Zn}$ and $\mathrm{Pb}$ in $\mathrm{F} 2<20-\mu \mathrm{m}$ fractions from sonification of different $\mathrm{F} 1>20-\mu \mathrm{m}$ fractions and enrichment factors (EF) expressed as the ratio of the concentrations in the F2 $<20-\mu \mathrm{m}$ fractions and their concentrations in the pre-sonification F1 $20-\mu \mathrm{m}$ fraction

\begin{tabular}{|c|c|c|c|c|c|c|c|c|}
\hline \multirow[b]{2}{*}{ Fraction / $\mu \mathrm{m}$} & \multicolumn{4}{|l|}{ Cambisol } & \multicolumn{4}{|l|}{ Ferralsol } \\
\hline & $\mathrm{F} 2<20 \mu \mathrm{m} / \mathrm{mg} \mathrm{kg}^{-1}$ & $\mathrm{EF}$ & $\mathrm{F} 2<20 \mu \mathrm{m} / \mathrm{mg} \mathrm{kg}^{-1}$ & $\mathrm{EF}$ & $\mathrm{F} 2<20 \mu \mathrm{m} / \mathrm{mg} \mathrm{kg}^{-1}$ & $\mathrm{EF}$ & $\mathrm{F} 2<20 \mu \mathrm{m} / \mathrm{mg} \mathrm{kg}^{-1}$ & $\mathrm{EF}$ \\
\hline Ap horizon & & & & & Ap horizon & & & \\
\hline $200-2000$ & $323 \pm 7$ & 0.6 & $199 \pm 1$ & 1.1 & $380 \pm 4$ & 1.1 & $219 \pm 2$ & 1.5 \\
\hline $50-200$ & $463 \pm 1$ & 0.8 & $242 \pm 3$ & 1.3 & $468 \pm 2$ & 1.4 & $316 \pm 1$ & 2.2 \\
\hline Bw horizon & & & & & Bo2 horizon & & & \\
\hline $200-2000$ & $335 \pm 10$ & 0.6 & $245 \pm 5$ & 1.4 & $376 \pm 4$ & 1.1 & $172 \pm 1$ & 1.3 \\
\hline $50-200$ & $456 \pm 7$ & 0.8 & $264 \pm 1$ & 1.6 & $408 \pm 2$ & 1.2 & $148 \pm 2$ & 1.1 \\
\hline $20-50$ & $441 \pm 8$ & 0.8 & $427 \pm 67$ & 2.5 & $451 \pm 28$ & 1.4 & $271 \pm 2$ & 2.0 \\
\hline
\end{tabular}

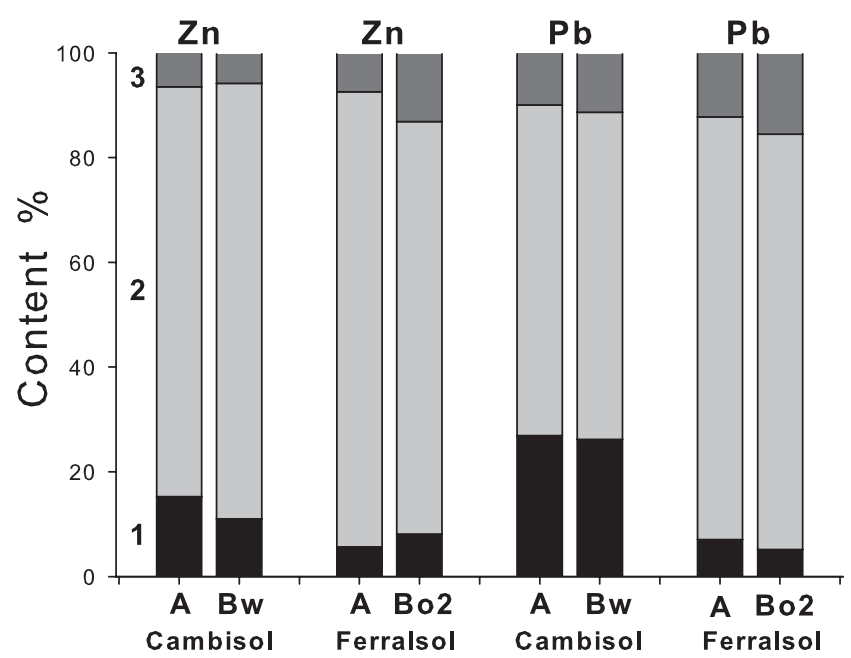

Figure 6 Contribution expressed as percentages of the amounts of $\mathrm{Zn}$ and $\mathrm{Pb}$ in size fractions to the total $\mathrm{Zn}$ and $\mathrm{Pb}$ amounts in bulk samples of $\mathrm{A}$ and B horizons of the Cambisol and Ferralsol. 1, F2 20-2000 $\mu \mathrm{m}$; 2, F1 $<20 \mu \mathrm{m} ; 3, \mathrm{~F} 2<20-\mu \mathrm{m}$ fractions.

for $\mathrm{Fe}$, with large concentrations in the iron nodule, and smaller concentrations in the groundmass (Figure 8b). Zinc was more diffusely distributed, and the overall correlation coefficient $r_{\mathrm{Zn} / \mathrm{Fe}}$ was $0.61(P<0.0001)$ (Figure $\left.8 \mathrm{c}\right)$, increasing to $r_{\mathrm{Zn} / \mathrm{Fe}}=$ $0.67(P<0.0001)$, when restricting the analysis to the microaggregated groundmass outside the iron nodule. In contrast, no correlation of $\mathrm{Zn}$ with $\mathrm{Fe}$ was observed $\left(r_{\mathrm{Zn} / \mathrm{Fe}}<0.1\right)$ within the iron nodule. The largest $\mathrm{Zn}$ concentrations occurred at the outer skin of the nodule. For $\mathrm{Mn}$ and $\mathrm{Pb}$, no distinct patterns were observed, indicating their diffuse distribution in the groundmass.

\section{Discussion}

\section{Metal-bearing source fractions}

The regional background levels for $\mathrm{Zn}$ and $\mathrm{Pb}$ in Ferralsols are estimated at about 45 and $40 \mathrm{mg} \mathrm{kg}^{-1}$, respectively (Burak et al., 2010). The $\mathrm{Zn}$ concentration was about five-fold and $\mathrm{Pb}$ about two-fold larger in the Ferralsol that we studied, and $\mathrm{Zn}$ and $\mathrm{Pb}$ concentrations were even larger in our Cambisol (Table 2) and exceeded the CETESB (2005) guidelines (300 mg kg-1 $\mathrm{Zn}$ and $72 \mathrm{mg} \mathrm{kg}^{-1} \mathrm{~Pb}$ ). In the absence of major anthropogenic metal inputs in these soils, these large concentrations indicate a geogenic origin. In the study area, carbonate rocks of the Ambrósia and Fagundes deposits were reported to be affected by hydrothermal alteration, leading to substitution of $\mathrm{Ca} / \mathrm{Mg}$ in dolomite by $\mathrm{Pb}$ and intergrowth of sphalerite/galena minerals, as well as an intense silicification and formation of interstitial fine-grained quartz (Monteiro et al., 2007). In our work, there was no direct evidence of the sulphides, $\mathrm{ZnS}$ or $\mathrm{PbS}$, in the Cambisol parent material. However, the common occurrence of iron pseudomorphes after cubic crystal clusters (Figures 3e, 7d) in the Cambisol strongly suggests their origin as a past alteration of sulphide minerals. Moreover, quartz with hematite inclusions (Figure 3f) is consistent with silicification/secondary hematite intergrowth (Monteiro et al., 2007).

Metal concentration distributions in $\mathrm{F} 2>50-\mu \mathrm{m}$ fractions, represent about $10-15 \% \mathrm{Zn}$, but reach $25-30 \% \mathrm{~Pb}$ in both soils, and are consistent with an inheritance hypothesis for the $\mathrm{Zn}$ and Pb-bearing minerals in coarse fractions. In 1000-2000$\mu \mathrm{m}$ fractions of the Cambisol, the largest concentrations of $\mathrm{Zn}$ and $\mathrm{Pb}$ were in iron-manganese pseudomorphs (Table 3). Their typical angular cubic cluster morphologies indicate that such FeMn nodules cannot result from pedogenetic accumulation, but are inherited from initial alteration in the dolomitic parent rock. Such findings were confirmed by $\mu$-XRF elemental mappings (Figure 7), and underline the close relationships between Fe, Mn, $\mathrm{Zn}$ and $\mathrm{Pb}$ in such inherited nodules of coarse-sand-sized, but also of silt-sized, grains in the Cambisol. During pedogenesis, $\mathrm{Zn}$ and $\mathrm{Pb}$ are transiently labile in the soil solution after weathering and subsequently sequestered by reactive fine soil phases, preferentially by sesquioxides. Because of erosion from dolomitic outcrops, located on the upper slopes, such metalbearing soil material is disseminated downward and progressively incorporated into the Ferralsols. 
a

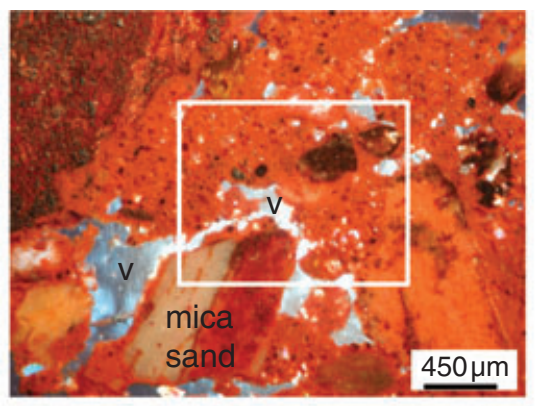

b
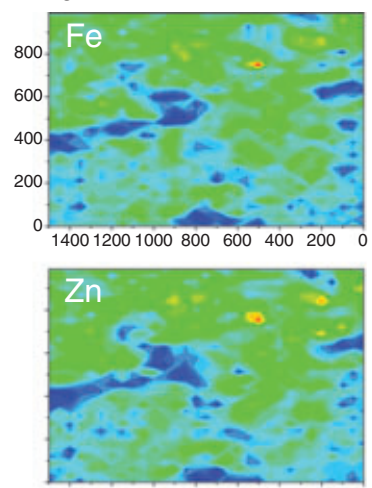
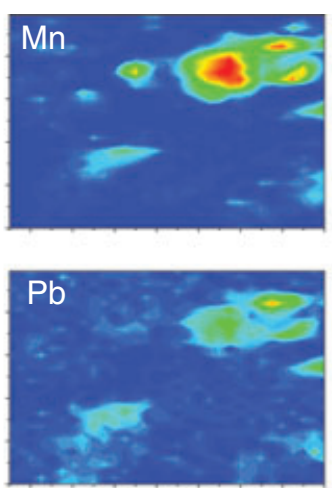
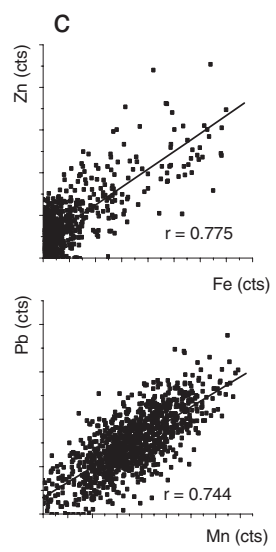

d

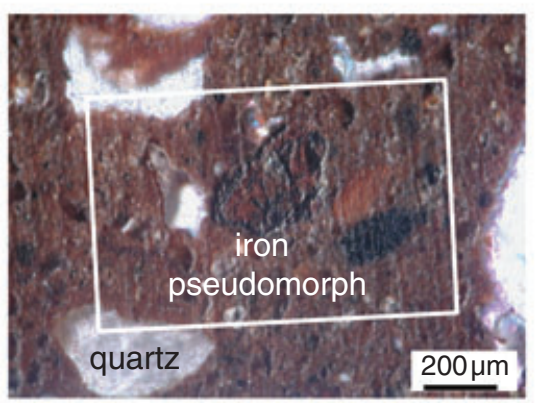

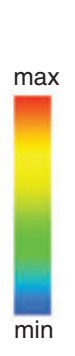

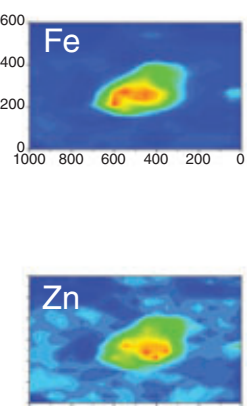

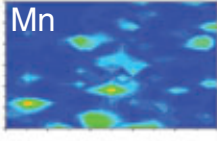

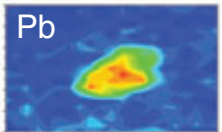

f
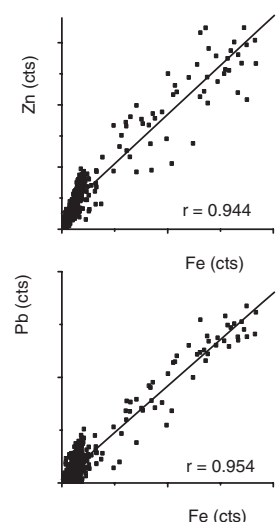

Figure 7 Optical microscopy and micro-X-ray fluorescence analysis of groundmass and pedofeatures in selected thin section areas of the Cambisol Bw horizon: (a) characteristic microstructure of the Cambisol, with a micaceous sand grain and reddish, iron-rich micro-aggregated groundmass including black manganese accumulations; (b) related $\mu$-XRF distribution maps of $\mathrm{Fe}, \mathrm{Mn}, \mathrm{Zn}$ and $\mathrm{Pb}$; (c) elemental correlation of $\mathrm{Zn}$ to $\mathrm{Fe}$ and $\mathrm{Pb}$ to $\mathrm{Mn}$, results expressed in counts/300 s $(P<0.0001)$, for an analysed area of $1500 \times 990 \mu \mathrm{m}^{2}(n=1054$ points); (d) sand-sized iron pseudomorph after a cubic crystal cluster in the groundmass; (e) related $\mu$-XRF distribution maps of $\mathrm{Fe}, \mathrm{Mn}, \mathrm{Zn}$, and $\mathrm{Pb}$; (f) elemental correlation of $\mathrm{Zn}$ to $\mathrm{Fe}$ and $\mathrm{Pb}$ to $\mathrm{Fe}(P<0.0001$ ), results expressed in counts per $530 \mathrm{~s}$, for an analysed area of $600 \times 1000 \mu \mathrm{m}(n=441$ points).

In the study region, dolomites with iron and manganeserich nodules were reported by Monteiro et al. (2007). Their morphology and large $\mathrm{Zn}$ and $\mathrm{Pb}$ concentrations indicate that the formation of the nodules and pseudomorphs probably relates to hydrothermal mineralization. Few other previous studies have highlighted the role of inherited Fe/Mn concretions as a primary source of trace metals in soils. Latrille et al. (2001) reported very large heavy metal contents in iron-manganese nodules inherited from the alteration of Sinemurian limestone in Burgundy. Iron, Mn and $\mathrm{Pb}$-rich components were identified by XRD as manganesesubstituted plumbojarosite (F. van Oort, personal communication) in Technosols on mine spoils from ore veins in dolomite in the Cevennes region.

\section{Metal-accumulating target fractions}

Intensive soil weathering under humid tropical conditions often leads to the formation of Ferralsols, which contain a coarse fraction of mainly weathering-resistant soil constituents (quartz), and fine fractions of stable secondary minerals such as 1:1 phyllosilicates (kaolinite) and iron and aluminium oxides (Fontes \& Weed, 1991). Because of its small electronegative charge, kaolinite is unimportant for metal sorption (Gu \& Evans, 2008), whereas the Fe-, Al- and to a lesser extent Mn-oxides are major secondary metal-bearing minerals (Singh \& Gilkes, 1992; Becquer et al., 2006). In our work, about $91-94 \%$ of total $\mathrm{Zn}$ and $\mathrm{Pb}$ in the Ferralsol and $85-90 \%$ of $\mathrm{Zn}$ and $70-75 \%$ of $\mathrm{Pb}$ in the Cambisol occurred in the $<20-\mu \mathrm{m}$ fractions. Comparison of $\mathrm{Zn}$ and $\mathrm{Pb}$ concentrations of the $<20-\mu \mathrm{m}$ fractions, before and after sonification, gave enrichment factors of $0.6-1.3$ for $\mathrm{Zn}$ and 1.1-2.6 for $\mathrm{Pb}$ (Table 4), pointing to some $\mathrm{Pb}$-enrichment of coatings and/or dispersed material in microaggregates.

For the Cambisol, sonification disaggregated consistent amounts of iron- and manganese-rich fine materials, such as oxideprecipitates on quartz grains, and micronodules and/or microaggregates. This explains the reduction of dark-red colours on sand grains (Figure $3 \mathrm{~g}-\mathrm{i}$ ) and the large $\mathrm{Zn}$ and $\mathrm{Pb}$ concentrations in 
a

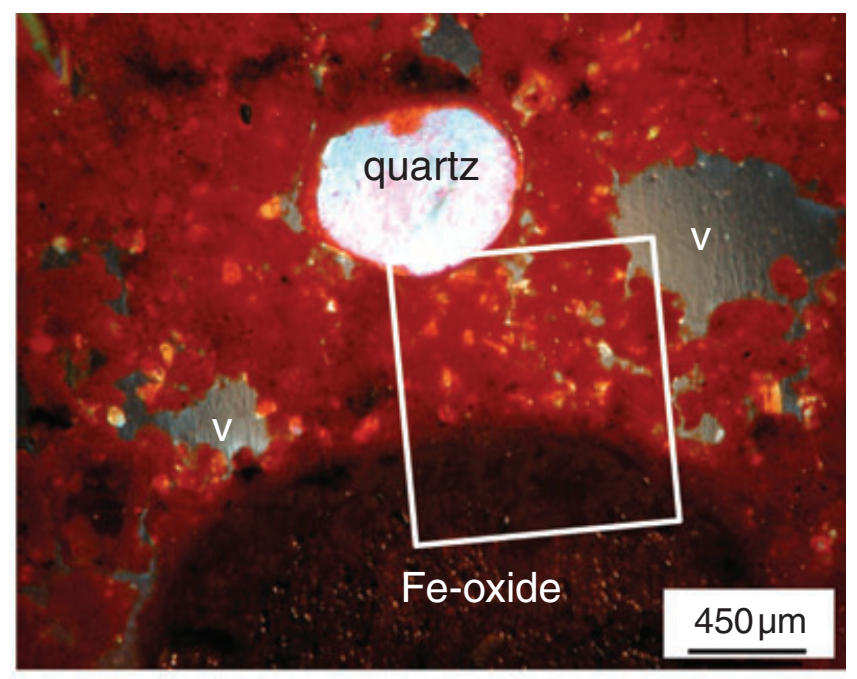

b
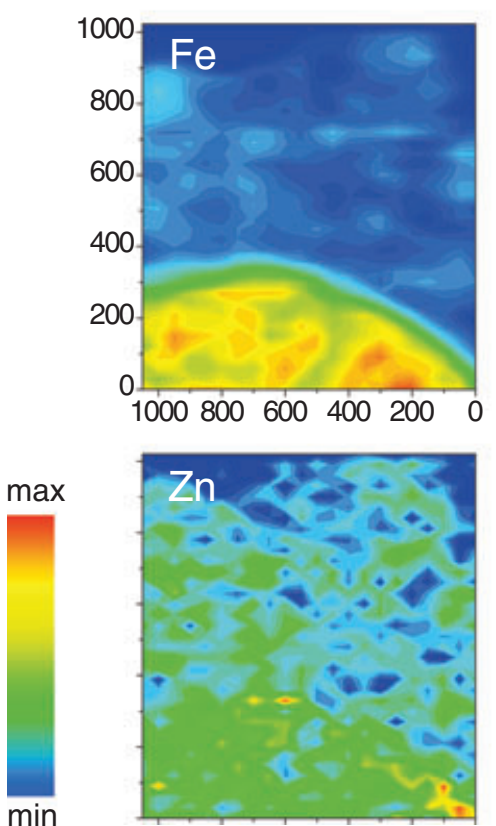
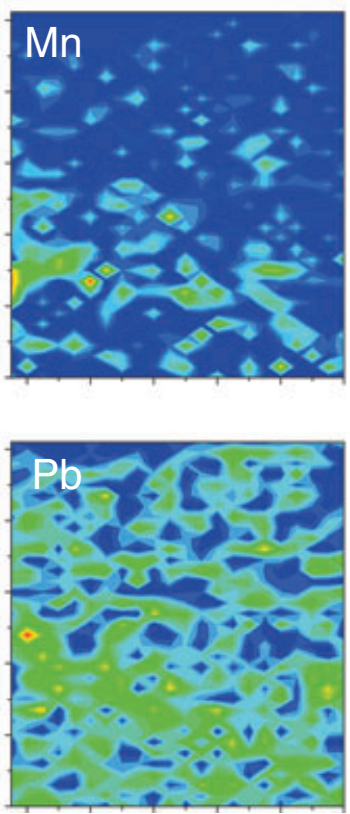

C
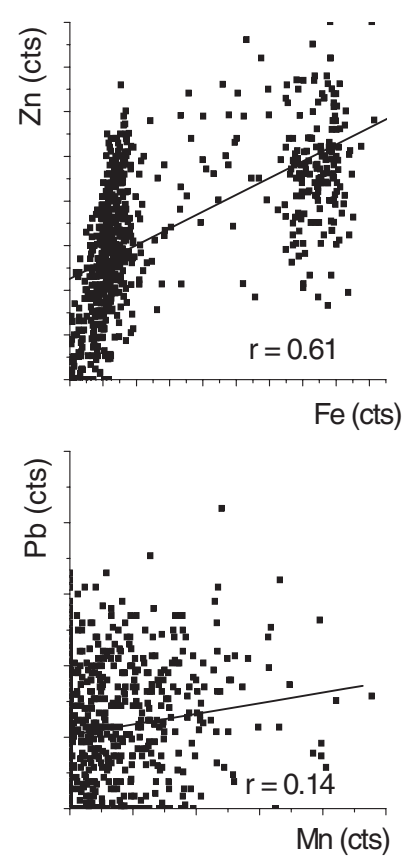

Figure 8 Optical microscopy and micro-X-ray fluorescence analysis on groundmass in a selected thin section area of the Ferralsol Bo2 horizon: (a) characteristic microstructure of the Ferralsol, with micro-aggregated groundmass embedding a rounded transparent quartz grain and a large iron nodule; (b) related $\mu$-XRF distribution maps of $\mathrm{Fe}, \mathrm{Mn}, \mathrm{Zn}$ and $\mathrm{Pb}$; (c) elemental correlation of $\mathrm{Zn}$ to $\mathrm{Fe}$ and $\mathrm{Pb}$ to Mn, results expressed in counts per $300 \mathrm{~s}(P<0.0001)$, for an analysed area of $1050 \times 1020 \mu \mathrm{m}(n=770$ points $)$.

recovered F2 $<20-\mu \mathrm{m}$ fractions. Dark-coloured concretions and nodules generally contain more $\mathrm{Mn}$ than lighter-coloured ones (Stoops, 2003). For the Cambisol Bw horizon, large metal enrichments in F2 $<20-\mu \mathrm{m}$ fractions gave an EF 5.5 for Mn (data not shown) and an EF 2.5 for $\mathrm{Pb}$ in the $20-50-\mu \mathrm{m}$ fraction (Table 4). Correlation $(n=6)$ between total major elements extraction and
$\mathrm{Pb}$ and $\mathrm{Zn}$ in recovered $\mathrm{F} 2<20-\mu \mathrm{m}$ fractions of Cambisol confirmed such preferential $\mathrm{Mn}-\mathrm{Pb}$ associations $\left(r_{\mathrm{Pb} / \mathrm{Mn}-\text { total }}=\right.$ $0.98, P<0.001)$ whereas $\mathrm{Zn}$ and $\mathrm{Mn}$ were poorly correlated $\left(r_{\mathrm{Zn} / \mathrm{Mn}-\text { total }}=0.38, P=0.38\right)$ as were the pairs $\mathrm{Fe}-\mathrm{Pb}, \mathrm{Fe}-\mathrm{Zn}$, $\mathrm{Al}-\mathrm{Pb}$ and $\mathrm{Al}-\mathrm{Zn}$ (correlations $P>0.1$ ). Additionally, only $\mathrm{Pb}$ was well correlated with the poorly crystalline manganese in 
$\mathrm{F} 2<20-\mu \mathrm{m}$ fractions $\left(r_{\mathrm{Pb} / \mathrm{Mn}-\mathrm{oxa}}=0.96, P<0.002\right)$, whereas the pairs $\mathrm{Pb}-\mathrm{Fe}-\mathrm{ox}, \mathrm{Zn}-\mathrm{Mn}$-ox and $\mathrm{Zn}-\mathrm{Fe}-\mathrm{ox}$ had correlations of $P>0.1$.

The large oxalate-extractable Mn proportion (about 70\%, Table 3) indicates that most $\mathrm{Mn}$ in the Cambisol was as disordered, poorly crystalline Mn-oxides in the fine groundmass and/or coated and infilling on quartz grains and/or cementing Mn-Fe nodules (Figure 7a). These results suggest a pedological origin for the strong $\mathrm{Pb}-\mathrm{Mn}$ associations in dispersible mineral coatings, microaggregates and poorly crystalline Fe-Mn nodules. In contrast, the $\mathrm{Zn}$ and $\mathrm{Pb}$ associations in more resistant, crystalline $\mathrm{Fe}-\mathrm{Mn}$ nodules are ascribed to inheritance from the mineralized parent rock.

Manganese oxide coatings often display a reduced crystallization and have greater specific surface when compared with Mn-oxide minerals (Boonfueng et al., 2005). Manganese oxides are often included among the most efficient metal-scavengers in soils (Manceau et al., 2003; Boonfueng et al., 2005). McKenzie (1989) estimated the $\mathrm{Pb}$ sorption on synthetic Mn-oxides to be 40 times greater than on synthetic Fe-oxides. In surface horizons, the greater affinity of $\mathrm{Pb}$ for organic matter is often used to explain its restricted mobility in soils. Poor correlations were observed in fine $\mathrm{F} 2<20-\mu \mathrm{m}$ fractions of both soils for $\mathrm{Zn}$ and $\mathrm{Pb}$ with organic carbon (Burak, 2008). Leaching of $\mathrm{Pb}$ is generally limited to minor colloid-facilitated transfers, in association with $\mathrm{Fe}$ or Mn-oxides (Citeau et al., 2003), and its accumulation at $>1$ $\mathrm{m}$ depth was attributed to the precipitation of such metal-bearing colloids (van Oort et al., 2006).

In the Ferralsol, larger $\mathrm{Fe}$ and $\mathrm{Al}$ concentrations were found in the $\mathrm{F} 2<20-\mu \mathrm{m}$ fractions than in the Cambisol as well as larger EF (1.1-1.3 and 1.0-1.2, respectively, data not shown). The $\mathrm{F} 2<20-\mu \mathrm{m}$ fractions consisted mainly of stable, oxide-rich microaggregates. Heavy metals, originating from geogenic contamination by dissemination from weathered dolomitic outcrops, associate preferentially with Al- and Fe-oxides in the Ferralsols (Vollant-Tuduri et al., 2004). Furthermore, the surfaces of the microaggregates are more favourable for metal sorption from water leaching laterally from the dolomite. Such spatial differentiation is consistent with the observed large $\mathrm{Zn}$ and $\mathrm{Pb}$ enrichment factors in the F1 20-50 $\mu$ m-derived F2 $<20$ $\mu \mathrm{m}$ fractions (Table 4). In addition, physical inaccessibility may also explain the distribution of heavy metal accumulating inside stable microaggregates, and account for the large $\mathrm{Zn}$ and $\mathrm{Pb}$ concentrations in the F2 $20-50-\mu \mathrm{m}$ fractions. Such physical protection could be important in the non-dissemination of $\mathrm{Pb}$ and $\mathrm{Zn}$ immobilized into the interiors of microaggregates, which is confirmed by the very poor DTPA extractability that was observed $(<1 \%$ for $\mathrm{Zn},<6 \%$ for $\mathrm{Pb})$.

\section{Conclusions}

The $\mathrm{Zn}$ and $\mathrm{Pb}$ concentration distributions in soil horizons of a Cambisol-Ferralsol sequence in the Brazilian Central Plateau are compatible with a geogenic metal source, originating from the weathering of mineralized dolomite. Combined chemical, XRD and optical microscopy of different size fractions obtained by physical fractionation in water, together with $\mu$-XRF elemental mapping on undisturbed soil thin sections, provided evidence for the hypothesis of geogenic metal origins. Typical microaggregated structures with large oxide contents provide favourable conditions for strong retention of $\mathrm{Zn}$ and $\mathrm{Pb}$ and limit their dissemination into a wider environment. Ultrasonification of coarse soil fractions produced additional fine $<20 \mu \mathrm{m}$ material with large $\mathrm{Zn}$ and $\mathrm{Pb}$ concentrations. These findings explain the role of fine, oxide-rich micro-aggregated soil material in metal-accumulation. In contrast, sand fractions are predominantly composed of quartz and silcrete with small $\mathrm{Zn}$ and $\mathrm{Pb}$ concentrations. However, in the Cambisol, the coarse sand fraction included a significant proportion of iron and manganese pseudomorph concretions with very large $\mathrm{Zn}$ and $\mathrm{Pb}$ concentrations. These differ from those in the $<20-\mu \mathrm{m}$ fraction, where $\mathrm{Pb}$, especially, is associated with easily dispersible Mn-rich poorly crystalline compounds. Hence, soil formation processes lead to Mn-rich microstructures and pedofeatures favouring $\mathrm{Pb}$ retention in the Cambisol and to stable, Aland Fe-oxide-rich microaggregates containing large amounts of strongly bound $\mathrm{Zn}$ and $\mathrm{Pb}$ in the Ferralsol. These poor mobilities and bioavailablities because of sorption on different types of sesquioxides reduce the risk of $\mathrm{Zn}$ and $\mathrm{Pb}$ toxicities in these soils.

\section{Acknowledgements}

This work and the fellowship for DLB were supported by the Brazilian-French Cooperation Programme Capes-Cofecub (Project NO. 514-05). The work was part of the project EMBRAPA Cerrados/IRD NO 0203205. We greatly acknowledge Amélie 'Formiga' Trouvé, Sébastien Breuil and Anne Jaulin (Inra-Pessac, Versailles) for technical assistance, quality-control and validation of analytical data. We would like to thank two anonymous reviewers and the associate editor for valuable suggestions and remarkable editorial work.

\section{References}

Balesdent, J., Petraud, J.P. \& Feller, C. 1991. Effet des ultrasons sur la distribution granulométrique des matières organiques des sols. Science du Sol, 29, 95-106.

Becquer, T., Quantin, C., Rotté-Capet, S., Ghanbaja, J., Mustin, C. \& Herbillon, A.J. 2006. Sources of trace metals in Ferralsols in New Caledonia. European Journal of Soil Science, 57, 200-213.

Binns, R.A. 2006. Data report: petrography and geochemistry of jasperoids from Site 1189, Ocean Drilling Program Leg 193. In: Proceedings of the Ocean Drilling Program, Scientific Results, Volume 193 (eds F.J.A.S. Barriga, R.A. Binns, D.J. Miller \& P.M. Herzig), pp. 1-30. [WWW document]. URL http://www-odp.tamu.edu/publications/193_ SR/211/211.htm [accessed on 15 October 2012].

Boonfueng, T., Axe, L. \& Xu, Y. 2005. Properties and structure of manganese oxide-coated clay. Journal of Colloid \& Interface Science, 281, 80-92.

Buol, S.W. \& Eswaran, H. 2000. Oxisols. Advances in Agronomy, 68, $151-195$ 
Burak, D.L. 2008. Geoquímica e distribuição espacial de metais pesados em solos da região de Unaí, Paracatu e Vazante, MG. $\mathrm{PhD}$ thesis, University of Viçosa, Viçosa-MG, Brasil.

Burak, D.L., Fontes, M.P.F., Santos, N.T., Monteiro, L.V.S., Martins, E.S. \& Becquer, T. 2010. Geochemistry and spatial distribution of geogenic heavy metals in Oxisols in a mineralized region of the Brazilian Central Plateau. Geoderma, 160, 131-142.

CETESB 2005. Decisão de diretoria $n^{\circ}$ 195-2005-e-aprovação dos valores orientadores para solos e águas subterrâneas no estado de São Paulo. CETESB, São Paulo.

Citeau, L., Lamy, I., van Oort, F. \& Elsass, F. 2003. Colloidal facilitated transfer of metals in soils under different land use. Colloids \& Surfaces A: Physicochemical \& Engineering Aspects, 217, 11-19.

Dardenne, M.A. 1979. Les minéralisations de plomb, zinc, fluor du Protérozoïque supérieur dans le Brésil central. $\mathrm{PhD}$ thesis, University of Paris VI, Paris.

Ducaroir, J. \& Lamy, I. 1995. Evidence of trace metal association with soil organic matter using particle size fractionation after physical dispersion treatment. Analyst, 120, 741-745.

Fernandez, C., Monna, F., Loubet, M. \& van Oort, F. 2008. Lead mobility in soils under permanent grassland and arable land estimated from $\mathrm{Pb}-$ isotopic compositions. Environmental Pollution, 156, 1083-1091.

FitzPatrick, E. 1970. A technique for the preparation of large thin sections of soils and unconsolidated material. In: Micromorphological Techniques and Applications, Technical Monograph, Volume 2 (eds D.A. Osmond \& P. Bullock), pp. 3-13. Soil Survey of England and Wales, Harpenden.

Fontes, M.P.F. \& Weed, S.B. 1991. Iron oxides in selected Brazilian Ferralsols: 1. Mineralogy. Soil Science Society of America Journal, 55, 1143-1149.

Gu, X.Y. \& Evans, L.J. 2008. Surface complexation modelling of Cd(II), $\mathrm{Cu}(\mathrm{II}), \mathrm{Ni}(\mathrm{II}), \mathrm{Pb}(\mathrm{II})$, and $\mathrm{Zn}$ (II) adsorption onto kaolinite. Geochimica et Cosmochimica Acta, 72, 267-276.

IUSS Working Group WRB 2006. World Reference Base for Soil Resources, 2nd edn, World Soil Resources Reports, No 103. FAO, Rome.

King, L.C. 1956. A Geomorfologia do Brasil Oriental. Revista Brasileira de Geografia, 18, 147-265.

Labanowski, J., Sebastia, J., Foy, E., Jongmans, A.G., Lamy, I. \& van Oort, F. 2007. Fate of metal-associated POM in a soil under arable land use contaminated by metallurgical fallout. Environmental Pollution, 149, 59-69.

Latrille, C., Elsass, F., van Oort, F. \& Denaix, L. 2001. Physical speciation of trace metals in Fe-Mn concretions from a rendzic lithosol developed on Sinemurian limestones (France). Geoderma, 100, 127-146.

Lindsay, W.L. \& Norvell, W.A. 1978. Development of a DTPA soil test for zinc, iron, manganese, and copper. Soil Science Society of America Journal, 42, 421-428.

McKeague, J.A. \& Day, J.H. 1966. Dithionite and oxalate-extractable Fe and $\mathrm{Al}$ as aids in differentiating various classes of soils. Canadian Journal of Soil Science, 46, 13-22.
McKenzie, R.M. 1989. The adsorption of lead and other heavy metals on oxides of manganese and iron. Australian Journal of Soil Research, 18, 61-73.

Manceau, A., Tamura, N., Celestre, A., MacDowell, A.A., Geoffroy, N., Sposito, G. et al 2003. Molecular-scale speciation of $\mathrm{Zn}$ and $\mathrm{Ni}$ in soil ferromanganese nodules from loess soils of the Mississippi Basin. Environmental Science \& Technology, 37, 75-80.

Marques, J.J., Schulze, D.G., Curi, N. \& Mertzman, S.A. 2004a. Major element geochemistry and geomorphic relationships in Brazilian Cerrado soils. Geoderma, 119, 179-195.

Marques, J.J., Schulze, D.G., Curi, N. \& Mertzman, S.A. 2004b. Trace element geochemistry in Brazilian Cerrado soils. Geoderma, 121, 31-43.

Mehra, O.P. \& Jackson, M.L. 1960. Iron oxide removal from soils and clays by a dithionite-citrate system buffered with sodium bicarbonate. Clays \& Clay Minerals, 7, 317-327.

Misi, A., Iyer, S.S.S., Coelho, C.E.S., Tassinari, C.C.G., Franca-Rocha, W.J.S., Cunha, I.A. et al. 2005. Sediment hosted lead-zinc deposits of the Neoproterozoic Bambuí Group and correlative sequences, São Francisco Craton, Brazil: a review and a possible metallogenetic evolution model. Ore Geology Reviews, 26, 263-304.

Monteiro, L.V.S., Bettencourt, J.S., Juliani, C. \& de Oliveira, T.F. 2007. Nonsulfide and sulfide-rich zinc mineralizations in the Vazante, Ambrósia and Fagundes deposits, Minas Gerais, Brazil: mass balance and stable isotope characteristics of the hydrothermal alterations. Gondwana Research, 11, 362-381.

Semlali, R.M., van Oort, F., Denaix, L. \& Loubet, M. 2001. Estimating distributions of endogenous and exogenous $\mathrm{Pb}$ in soils, using $\mathrm{Pb}$ isotopic ratios. Environmental Science \& Technology, 35, 4180-4188.

Singh, B. \& Gilkes, R.J. 1992. Properties and distribution of iron oxides and their association with minor elements in the soils of south-western Australia. Journal of Soil Science, 43, 77-98.

Stoops, G. 2003. Guidelines for Analysis and Description of Soil and Regolith Thin Sections. Soil Science Society of America Inc., Madison, WI.

Teixeira, J.B.G., Misi, A. \& Silva, M.G.S. 2007. Supercontinent evolution and the Proterozoic metallogeny of South America. Gondwana Research, 11, 346-361.

van Oort, F., Jongmans, A.G., Citeau, L., Lamy, I. \& Chevallier, P. 2006. Microscale $\mathrm{Zn}$ and $\mathrm{Pb}$ distribution patterns in subsurface soil horizons: an indication for metal transport dynamics. European Journal of Soil Science, 57, 154-166.

van Oort, F., Lamy, I., Baize, D., Jongmans, A.G. \& Chevallier, P. 2008. Impacts of long-term waste-water irrigation on the development of sandy Luvisols: consequences for metal pollutant distributions. European Journal of Soil Science, 59, 925-938.

Vollant-Tuduri, N., Brossard, M., Bruand, A. \& Garreau, H. 2004. Direct analysis of microaggregates shrinkage for drying: application to microaggregates from a Brazilian clayed Ferralsol. Comptes Rendus de l'Académie des Sciences, 336, 1017-1024. 